\title{
New computer link for Japan
}

\section{Mishima}

THE DNA Data Bank of Japan (DDBJ) at the National Institute of Genetics in Mishima will this month open a highcapacity computer link that will allow exchange of much larger volumes of data with DNA databanks in Europe and the United States. But Japan's contribution to international efforts to handle the growing flood of DNA data remains pitifully small.

At a time when GenBank in the United States and the EMBL Data Library each employ teams of tens of researchers to run their databanks, Japan still struggles along with only two full-time researchers and a couple of part-timers at DDBJ. Not surprisingly, DDBJ at present processes only about 3 per cent of all the DNA sequences published worldwide; the remaining 97 per cent are dealt with at EMBL and GenBank.

DDJB constantly exchanges data with EMBL and GenBank and the volume of traffic has grown to over 1 million bits per day. This volume is expected to grow at least five times when the databanks move to a new relational database system in the near future, according to Sanzo Miyazawa of DDBJ. Hence the need for the highcapacity computer link.

The new computer line, which will be connected on 28 March and can carry 64 kilobits per second, is between DDBJ and the University of Tokyo.

Last year, the university opened Japan's first high-capacity computer link with the outside world, the Todai International Science Network, with a leased line to the University of Hawaii (see Nature 340, 670; 1989). DDBJ will gain access to scientific networks in the United States and Europe and thence to the GenBank and EMBL databases through Tokyo University. The new link will also allow DDJB to form a distributed database with DNA databanks at several locations in Japan.

The three databanks have agreed that from now on DDBJ will process all DNA sequences produced in Japan. This will increase DDBJ's data share to about 10 per cent. But the bank is in desperate need of more manpower to handle the increased workload. The rigid employment policies of the Ministry of Education, Science and Culture (MESC), to which DDBJ is affiliated, make it very difficult for the bank to employ new staff. DDBJ has won permission to create a new position for an assistant professor but more temporary staff are also needed for annotating DNA sequences as they are input.

The new leased computer line will also be a considerable drain on DDBJ's very limited budget. Despite privatization of the telecommunications industry several years ago, Japan's domestic telecommuni- cation charges remain very high compared with those of other developed nations. The charges for leasing the line to Tokyo University will be nearly $¥ 5$ million $(\$ 33,000)$ a year, or 50 per cent of the bank's annual grant. But, Miyazawa expects to get a new grant from MESC to cover these extra costs.

The lack of IBM-compatible computers in Japan also adds to DDBJ's headaches. Japan is the only developed nation where IBM-compatible personal computers are not the standard; rather, the market is dominated by NEC computers. GenBank recently developed the new software 'authorin' which allows scientists to input DNA sequences directly to databanks, thereby easing the workload for the databanks. But the software is of virtually no use in Japan until Miyazawa rewrites it into NEC-compatible form, something he hopes to do this summer. In any case, few Japanese biologists are computer-literate and it is likely to be a long time before large amounts of data are submitted in this way.

Japan also lags behind GenBank and the EMBL data library in the use of CD-
ROM to distribute DNA data to scientists. EMBL began using CD-ROM last September and GenBank began this month. But DDBJ continues to use magnetic tapes, which are cumbersome and hold fewer data, because there is little demand for such a service from Japanese scientists and the tapes are easier to copy, Miyazawa says.

Japanese researchers promoting the human genome project are considering Mishima as a possible site for a new bioinformation centre to handle data arising from the project. But although it is "quite possible" that the centre will be located at the National Institute of Genetics, it will probably be separate from DDBJ, according to Takeshi Seno of the institute.

Miyazawa says that DDJB simply does not have the capability to cope with the massive amount of data that is expected to arise from the human genome project. Some members of the institute fear that the centre will be a "service-orientated" facility providing information to researchers throughout Japan and their duties for the centre will cut into valuable research time. As it is, Miyazawa and his assistant have very little time for their own research because of commitments to DDBJ.

David Swinbanks

HEALTH RISKS

\section{DoE to give up studies?}

\section{Washington}

AN independent panel assembled to advise the Department of Energy (DoE) on its troubled epidemiology programme is expected to report this month that longterm studies on the effects of radiation and chemical hazards at DoE facilities cannot be credibly done by the department.

Kristine Gebbie, the panel's chair and Washington state's senior health official, says that the panel's draft report will recommend that DoE provide financial support for another agency such as the Department of Health and Human Services (HHS) to carry out long-term epidemiological studies.

"DoE's credibility has been attacked by so many people", Gebbie says. The agency "has to break down the overwhelming perception that it is a closed shop". Reforming the programme is one element of DoE director Admiral James Watkins' 'ten-point plan' to rebuild the agency. DoE has been accused of distorting and suppressing the results of epidemiological studies and of putting pressure on researchers who study the health of its workers.

At an advisory panel hearing in Columbia, South Carolina, last month, Gregg Wilkenson, a Los Alamos National Laboratory researcher, testified that DoE officials had put pressure on him to rewrite a report showing that workers at
DoE's Rocky Flats plutonium processing plant near Denver, Colorado, had higher than average cancer rates. Wilkenson said that in 1986 and 1987, while he was the laboratory's epidemiology group leader, he was asked to make the report appear more favourable to DoE.

Watkins has called for an investigation of Wilkenson's charges. "I am disturbed by even the allegation of DoE interference. I feel strongly that the independence of scientists to do their research and publish without departmental interference is critical to the credibility of their research and findings."

But Los Alamos spokesman John Webster says the laboratory has investigated the allegations and found no evidence of wrongdoing. "There was no attempt to berate Dr. Wilkenson", Webster says. "The study was published as written." Congressional critics are unlikely to be satisfied with the changes DoE is planning for its epidemiology programme. Senator Tim Wirth (Democrat, Colorado) plans to continue a legislative effort to move the entire effort - management and all - out of the energy agency and into HHS. His aides say that he is concerned that if the heart of the programme is allowed to stay in DoE, it may revert to secrecy and censorship once Watkins has left the agency. 